[from p. 2]

an Eastern European point of view, is flled with more hope and possibility for social justice than is Poland's. Neither the memory of Pyjas, Poland's dissident movement, Poles themselves, nor other Eastern Europeans concerned with human liberties are served by articles such as Franco's.

The Rev. Charles G. Robertson, Jr.

\author{
Pastor, Howesville Presby- \\ terian Church \\ Jasonville, Ind.
}

Thomas C. Franco Responds:

Robertson twists logic as well as meaning when he centers his attack on my so-called "factual error of omission."

I described how the Polish Government manages to keep social and political tensions within manageable limits. Robertson demonstrates his misunderstanding of the article when he states that no other explanation for the failure of the Pyjas protest is offered than bad timing. If factual error is the question here, I'm afraid he makes some rather serious ones.

A delicate balance exists in Poland. Robertson incorrectly characterizes this state of affairs as being "hopeful." Though the "Darkness at Noon" myth of an omnipotent and omnipresent party is hard to maintain in a country where the government shakes in its boots to raise the price of meat, the situation is far from "hopeful." The Pyjas story is proof of this fact.

The party leadership cannot afford to pursue a course of confrontation in Poland. Instead, domestic dissidents and critics of party policy are tackled by what the government calls "political means."

The method employed in the Pyjas case was direct and simple. Explanations in the press concerning his suspicious death were grounded in real or believable tensions; they began with details that were or seemed verifiable and ended up with some far-fetched interpretation, such as the story that Pyjas was secretly an informant.

The official response was to protect the citizens from anything that would interfere with their being content with the state. And the government's tactics succeeded. Contrary doubts outweighed the beliefs that began to crystallize into a political threat.

Robertson paints a false picture of my attitude about this point, and bases his criticisms on "hearsay" evidence. This unfortunate irony ought to be stressed. Pyjas was not accepted as a martyr by "thousands" of demonstrating students, as Robertson's romantic friends would lead us to believe. That's an honest-to-goodness factual error.

The most striking aspect of the Kracow protest was how fast it ebbed. What remains of Stanislaw Pyjas will never become the subject matter of tragedy.

\section{Sadat as Superstar}

To the Editors: My attention has been drawn to Abraham Martin Murray's comments on a Middle East Memo I prepared on February 15 for the Conference of Presidents of Major American Jewish Organizations entitled "Anwar Sadat, Superstar" ("A View of the World,"Worldview, April). I respect your right to a different opinion on who is responsible for the stalemate in the Middle East peace negotiations, but you have misinformed your readers by falsely stating that "the Conference's contribution is to advance the proposition that there was nothing awesome or courageous at all" about what Sadat did in visiting Jerusalem.

In fact, when President Sadat met in Jerusalem with Prime Minister Begin, the Conference of Presidents hailed that visit. When the Carter administration failed to recognize the historic nature of President Sadat's initiative, it was the Jewish community, led by the Conference of Presidents, that urged the president to accept Sadat's invitation to peace talks and to continue what we called the "powerful momentum" toward peace launched by the first SadatBegin meeting.

Even when President Sadat abruptly and without reason broke off the peace negotiations on January 18, Rabbi Schindler, in an open letter of reply to Sadat's letter to the American Jewish community, said, in part:

"History will remember and honor you for daring to speak in Jerusalem of peace between Arab and Jew.... Though we have not yet found a common way, we do share a common purpose. It is a lofty purpose, worthy of our striving: Peace with justice, not only to avoid the tragedies of the past but to reap that rich harvest of the better life which the full and free and cooperative effort between Egypt and Israel, born of peace, can bring."

I cite these statements to underscore the eagerness with which the Conference of Presidents embraced $\mathrm{Mr}$. Sadat's courageous and dramatic flight to Jerusalem. Unfortunately it has since become clear that President Sadat's breaking off of negotiations was not an aberration but part of a carefully calculated plan to cast Israel in the role of the intransigent and obdurate party. In his address to the People's Assembly in Cairo on January 21 (three days after abruptly recalling his foreign minister from Jerusalem) President Sadat revealed his true position, declaring:

"I understand and agree that, indeed, the negotiations should be conducted the way they are conducted all over the world, and that we should meet halfway, but only after Israel has first withdrawn to her 1967 borders. Afterwards, we should sit together and say, what is it we should attain in order to achieve peace? When we have reached that position we can talk about half from them and half from us."

In sum, Sadat insists that only when all the Israelis have withdrawn from Sinai, Gaza, the West Bank, Golan, and East Jerusalem is he prepared to sit down and negotiate the form of a settlement. This is not a prescription for peace; it is a formula for surrender.

We do not underestimate Sadat's "concession" in recognizing Israel's right to exist. But this is only the first step toward a settlement, a necessary beginning, but surely not the final commitment Egypt must make if there is to be peace. Yet President Sadat continues to act as if this is all he must do for peace, insisting that his promises are all that Israel needs for its security.

I do not know if Sadat really believes such foolishness, but he certainly acts as if he does-and it is this posturing, this exploitation of the media to advance these purposes and not the cause of peace that I found so objectionable, dubbing him "superstar." I regret that you found the term offensive. But apparently I am not the only one to regard him so. This is what Joseph Kraft had to say in his column in the Washington Post on May 7, 1978:

"When it comes to showmanship, histrionics and flair for the dranatic, Pres- 
ident Anwar Sadat outdoes Brando conceived by Cecil B. DeMille.

"He initiated the present phase with the electrifying trip to Jerusalem. He followed that by meeting Prime Minister Menachem Begin at Ismailia. Then came a sheer piect of stagecraft-a break in the negotiations for no apparent reason. That set up another superb scene-a visit to Washington and the charming of President Carter, the Congress and the American public."

Yes, I believe it is important to point out Anwar Sadat's posturings lest he believe that he can continue to charm and bamboozle the Carter Administration into thinking that he need do nothing more for peace than he has already done-and that all the risks for peace must be taken by Israel, and Israel only.

No progress for peace can come from such an attitude and such a policy.

Richard Cohen

\section{Conference of Presidents of Major American Jewish Organizations New York, N.Y.}

\section{"The Search for Disaster"}

To the Editors: Richard Neuhaus ("The Search for Disaster," Excursus, March) attacks the "cheerleaders of crisis" who see "disaster" as the "portent of desirable change." High on the list of undesirable "catastrophists" are those who presumably did not "want" (his emphasis) oil to be discovered under the North Sea. While those who speculate about the future cannot be said to share the same vision, the Neuhaus attack deserves some response.

A transformation of, or a transition from modern industrialism (capitalist or socialist) to some other social form need not be seen as "disaster" or "catastrophe." A world not dependent upon the automobile might not be all that bad. Recognition of planetary limits to growth might lead to more equitable food distribution as well as widespread sharing of all resources. And many of those who do the speculating hope to pave the way to avoiding catastrophe.

Admittedly, one who forecasts that something is likely to happen can be accused of wanting it to happen. Indeed,
I once heard Neuhaus label as "obscene" even a discussion of how we might stumble into "triage." Actually, a refusal to discuss it does not hide the fact that we already practice it, in that we are deliberately cutting back farm production to whatever can be sold at market price - even though those starving could use the food. Disaster, in other words, is built into the system we have now (capitalist or socialist). Perhaps inadvertently, Neuhaus opts for the status quo by implicitly rejecting projections that are not sufficiently optimistic.

Neuhaus is absolutely correct on one point, if for reasons he would not acc.spt. Because of the oil shortage, conventional war is no longer possible on any substantial scale. Old-style international conflict must inevitably lead to nuclear war - the only type of war now available to us. We can avoid it only by acknowledging the need for social transformation.

If there is a clear and present danger, it is provided by those like Neuhaus who, resolutely shutting out the available information, continue to assume that the oil under the North Sea (or in Alaska, Canada tar sands, or Colorado shale) really makes a difference. Now there's a recipe for disaster!

Frederick C. Thayer

Graduate School of Public and International Affairs

University of Pittsburgh

Pittsburgh, $\mathrm{Pa}$.

\section{From Shortage to Glut?}

To the Editors: In his essay, "Energy. Investment. Hua," in the March issue of Worldview, Norman Macrae presents the common short-term richnation view of a global problem. He states that we will have a glut of energy in the 1980's with present and projected prices. This may be true for a few of the rich nations, but that fact should be no surprise. The rich have always been able to provide themselves with a generous supply of material goods, particularly when prices go so high as to deny their use by the poor

The idea that the energy problem is solved when enough of the poor drop out of the market to leave a large supply for the rich is profoundly disturbing. It indicates a callous disregard for the role and fate of the major part of the global population. It totally disregards the reaction to the economic oppression within this deprived majority, a reaction that will certainly arise.

The global nature of the problem and recent changes in demand pattern are illustrated by the following facts. Since 1973 world energy demand growth rates have dropped from 4-6 per cent per annum to less than 1 per cent. But who has done all of this belt-tightening? Not the United States, with a continuing energy use growth rate of 4 per cent. Not even Western Europe and Japan, with recent energy growth rates of 1-2 per cent. The belt-tightening has occurred largely in the marginal industrialized countries. Italy has reduced energy consumption 5 per cent from 1972 . 73 levels. Spain, Greece, and Turkey have been stalled in their development efforts. The real conservation, in the harshest sense of the term, is being practiced in the underdeveloped nations. The truly poor nations are all being pressed toward total default on debts as they desperately try to cover costs of energy with new borrowing. Yet it is in such countries that we see per capital energy use declining by 10 per cent or more per year. The hope of economic development recedes before the pressure of an energy price that only inconveniences those who are higher on the economic scale.

Mr. Macrae does acknowledge the existence of problem areas in his discussion. He suggests that we may see more new Italies than new Germanies and Japans. I agree wholeheartedly. He also suggests a continued long-term growth in energy supply through massive investment in new sources such as breeders and fusion power. Again, this is energy for the rich at prices far beyond the reach of those who recently aspired to join the industrial development era.

We must address ourselves to the problem of inducing conservation practices involving major shifts in life-style in the rich nations. The global depressions and bankruptcies that will stem from present energy problems and responses will have a negative impact on all rich-nation economic performance that cannot be offset by Macrae's false glut.

Freeland, Mich 